\title{
Mandenkan
}

MANDENIKAN Bulletin semestriel d'études linguistiques mandé

\section{Kastenholz, Raimund. A corpus dictionary of Vai. Klingenheben's collection of lexical data}

(Archiv Afrikanistischer Manuskripte 9). Köln: Rüdiger Köppe Verlag, 2019.

\section{Alexandra Vydrina}

\section{(2) OpenEdition}

\section{Journals}

Electronic version

URL: https://journals.openedition.org/mandenkan/2312

DOI: $10.4000 /$ mandenkan.2312

ISSN: 2104-371X

Publisher

Llacan UMR 8135 CNRS/Inalco

Printed version

Number of pages: 111-114

ISSN: 0752-5443

Electronic reference

Alexandra Vydrina, "Kastenholz, Raimund. A corpus dictionary of Vai. Klingenheben's collection of lexical data", Mandenkan [Online], 63 | 2020, Online since 06 July 2020, connection on 08 July 2021. URL: http://journals.openedition.org/mandenkan/2312 ; DOl: https://doi.org/10.4000/mandenkan.2312

\section{(c) (i) (2)(2)}

Les contenus de Mandenkan sont mis à disposition selon les termes de la Licence Creative Commons Attribution - Pas d'Utilisation Commerciale - Partage dans les Mêmes Conditions 4.0 International. 


\section{Book review}

\section{Kastenholz, Raimund. A corpus dictionary of Vai. Klingenheben's collection of lexical data (Archiv Afrikanistischer Manuskripte 9). Köln: Rüdiger Köppe Verlag, 2019.}

The publication of the Vai dictionary based on August Klingenheben's collection and edited by Raimund Kastenholz is a very fortunate event for African studies. It finally makes the rich lexical database that was compiled by August Klingenheben (1886-1967) accessible. The thorough and consistent editorial work carried out by Kastenholz has made available the results of Klingenheben's research and documentation project on Vai, which, as we learn from the introduction, spanned a period of over forty years. The dictionary will doubtlessly serve as a very useful tool for further research on this language.

The Vai language is spoken in Liberia and Sierra-Leone by a total of 120000 people. ${ }^{1}$ The dictionary under review is not the first one published on this language. Sigismund Koelle's dictionary dates back to 1854, and Welmers and Kandakai finished their dictionary in 1974. Nevertheless, Kastenholz and Klingenheben's dictionary is unrivalled for its size: it contains 6300 entries as compared to the 1700 entries in the dictionary by Welmers and Kandakai (1974) and the even smaller dictionary by Koelle (1854). As for the state of research on the language, it should be noted that Vai has a relatively full though not very detailed grammatical description by Welmers (1976).

In general, due to the scrupulous work of the editor, the representation of the information is very clear and user-friendly. The entries of the dictionary contain various layers of information: apart from English equivalents, there are multiple crossreferences between entries including "synonyms, variants, majoritarian forms, minoritarian forms and archaic forms" (p. 9) and information about borrowing sources (mostly from English, but also from Arabic, French, Mende, etc.). Among the lemmas one finds a big number of compounds, with the morphological complexity indicated by dots that separate the morphemes. Apart from this, Kastenholz provides valuable comments that are often based on a comparison with equivalent forms in Welmers and Kandakai's (1974) dictionary. For example, for the noun kóníngái that Klingenheben translates as 'harp player, lute player', Kastenholz expresses his doubts concerning the meaning: "This glossing ('harp player') is neither consistent with the semantics of the following entry, nor with Welmers \& Kandakai's (1974), who note kóníngài 'framed

${ }^{1}$ This figure from Ethnologue is about twenty years old. The current number of speakers may be considerably bigger. 
flute' (p. 142). This is very helpful, since this allows the reader to take into account the information contained in Welmers and Kandakai's dictionary as well. Apart from this, in these comments Kastenholz sometimes also expresses his hypotheses concerning the morphological parsing and the meaning of a form that may diverge from Klingenheben's analysis. For example, with respect to the noun kjnji 'perfumes incense', he suggests that its meaning may be 'resin' with the form originating from $k \grave{y}$ 'tree' and $j i$ 'water'.

The dictionary is richly illustrated, with a considerable part of lemmas accompanied by examples that aid the understanding of how the words function in speech, and by idiomatic expressions involving the word. In the introductory remarks, Kastenholz provides brief sociolinguistic and genetic information about the language. He introduces Klingenheben and his work on Vai and explains the circumstances of the creation of the database. The section of the introduction entitled "principles of the presentation of the data" is mainly dedicated to the question of the realization of nasalization, but one can also learn from it about such phonological phenomena as the disappearance of the intervocalic /1/. Further, the introduction provides the alphabet where the phonetic IPA correspondences are given when the orthography diverges from it. The introduction ends with a very helpful description of the possible structure of the entries and the use of conventions, and a list of abbreviations used in the dictionary. It would have been helpful, though, to add a short description of the main grammatical features of the language, such as the basic word order, the auxiliaries and the main inflectional markers. The inclusion of some general grammatical information would have facilitated the use of the dictionary and would make it easier to understand the examples in Vai. One also misses the description of some basic properties of the phonological system of the language (tonal oppositions, the presence or absence of tonal processes, etc.) and the presentation of the most widespread allomorphic variation. For example, the entry kìn 'tree' on p. 143 contains the example kóm bilà (lit. 'to let go of the stick'). As can be seen, the final nasal and the tone of the form meaning 'stick/tree' in the example are different as compared to the entry form, and it leaves the reader wondering about the reasons of this variation. One also misses some explanation about the nominal morphology: as can be deduced from examples, Vai nouns often appear in sentences accompanied by a suffix. This appears to be an article, yet the reader can only try to guess how this form is derived and what is its precise function.

Among the few minor deficiencies in the presentation of Vai forms in the dictionary one can mention the absence of tonal notation for some words, e.g. Bowakai (personal noun), bundu 'leafstalk'. Does the absence of tone reflect some phonological reality or is it simply due to the lack of information in Klingenheben's database? No 
clarification concerning such cases of the absence of tonal notation are provided in the introduction.

Next, the presentation of morpheme boundaries seems to be inconsistent sometimes, in particular in the case of reduplicated forms. For example, for the ideophones gbèygí.gbèygi 'in a hobbling, toddling way', kúwúyá.kùwùyà '(to walk) boastfully, in a proud way' the repeated elements are separated, but there is no separation for cases which seem to be identical in terms of morphological structure, cf. gbónmgbón 'in a staggering, tottering, teetering way', and gbùngbùlù 'stout, short, and strong build', kàyàkàyà 'in a limping, hobbling way'.

In general, apart from providing valuable and variegated information about the lexical forms, this dictionary can also serve as an interesting source for observing certain phonological phenomena. Even for a person not familiar with the phonology of Vai, the dictionary allows to figure out the highly intricate and curious functioning of nasalization in this language. This understanding is possible to arrive at due to the consistent use of transcription that is provided in square brackets after a certain number of lemmas and due to the explanations provided in the introduction to the dictionary. A particularly interesting case is the difference in the functioning of nasalization with respect to the consonant $/ \mathrm{v} /$. As Kastenholz explains in the introduction, $/ \mathrm{v} /$ is automatically nasalized $[\tilde{\mathrm{v}}$ ] in the following three contexts: followed by $/ \mathrm{n} /, / \mathrm{y} /$ or by a nasalized vowel. Accordingly, when the head of the entry contains such a consonant that is realized with nasalization, it is followed by transcription. At the same time, the author may be somewhat too demanding towards the reader, who is an ordinary linguist, and some more explicitness would have been helpful to guide the reader in understanding the complex Vai nasalization. Thus, the reader has to be very attentive not to miss any piece of information in order to understand the use of transcription reflecting nasalization. Thus, at the first reading of the nasalization principle concerning $/ \mathrm{v} /$, I was confused by the fact that the word vànjà 'type of cloth embroidered with pearls' on p. 254 is not accompanied by the transcription, whereas the word vàná [vàná] 'sinew' just before does have such an annotation. I first took it as an inconsistency in the use of transcription, thinking that vànjà is also a context in which nasalization takes place and it is therefore realized with a nasalized /v/. Yet, when I referred back to the explanations in the introduction, I realized that phonologically, $/ \mathrm{n} /$ in vànjà is not a separate consonant, but rather a secondary articulation feature of the palatal consonant $/ \mathrm{j} /$. Therefore, going back to the description of the automatic nasalization context for $/ \mathrm{v} /$, it should be taken into account that this consonant is nasalized not before any $/ \mathrm{n} /$ or $/ \mathrm{y} /$ but only before those that represent a full-fledged consonant. 
However, these minor remarks do not change the fact that Klingenheben's Vai dictionary prepared for publication by Kastenholz is an extremely rich and useful source of information on the Vai language.

\section{References}

Koelle, S. W. 1854. Outlines of a Grammar of the Vei Language. Together with a VeiEnglish Vocabulary. London.

Welmers, W. E. \& C. K. Kandakai. 1974. A Vai-English dictionary (preliminary draft). Monrovia, ms.

Welmers, William. 1976. A Grammar of Vai. Berkeley: University of California Press.

Alexandra Vydrina, Higher School of Economics, Moscow 